\title{
ANALISIS KETERAMPILAN BERBICARA MELALUI PENGGUNAAN BUKU CERITA BERGAMBAR PADA MATA PELAJARAN BAHASA INDONESIA SISWA KELAS III SD NEGERI PASAR BARU 1 KOTA TANGERANG
}

\author{
Vivi Dian Pratiwii ${ }^{1}$, Enawar ${ }^{2}$, Dilla Fadhillah ${ }^{3}$, Sumiyani $^{4}$ \\ Universitas Muhammadiyah Tangerang, Kota Tangerang \\ pratiwivividian@gmail.com, enawar.abah@gmail.com, dillafadhillah89@gmail.com, \\ sumiyaninitura@gmail.com
}

\begin{abstract}
ABSTRAK
Keterampilan berbicara adalah salah satu keterampilan berbahasa, dimana keterampilan berbicara sangat penting dan berhubungan erat dalam pembelajaran untuk melakukan suatu komunikasi, untuk mengungkapkan ide, pikiran, gagasan serta isi hati dengan baik. Permasalahan yang dibahas dalam penelitian ini yaitu bagaimana keterampilan berbicara melalui penggunaan buku cerita bergambar pada mata pelajaran bahasa indonesia siswa kelas III. Penelitian ini bertujuan untuk mendeskripsikan keterampilan berbicara melalui penggunaan buku cerita bergambar pada mata pelajaran bahasa indonesia siswa kelas III di SD Negeri Pasar Baru 1 Kota Tangerang. Penelitian ini adalah penelitian kualitatif dengan subjek 20 siswa pada kelas III dan guru kelas III. Teknik yang digunakan untuk mengumpulkan data adalah Tes, Wawancara Guru kelas III, Observasi Guru kelas III, Observasi Siswa kelas III, dokumentasi dan Analisis data yang dilakukan dengan reduksi data, penyajian data, dan menarik kesimpulan. Simpulan hasil penelitian ini menunjukkan bahwa keterampilan berbicara melalui penggunaan buku cerita bergambar sudah cukup baik, pada 7 aspek yang dinilai yaitu: kesesuaian isi cerita, ketepatan penunjukkan detil cerita, ketepatan logika cerita, ketepatan makna keseluruhan cerita, ketepatan kata, ketepatan kalimat, kelancaran, dari 20 siswa terdapat 8 siswa yang belum memenuhi aspek keterampilan berbicara melalui buku cerita.

Kata Kunci: Keterampilan Berbicara, Buku Cerita Bergambar.
\end{abstract}

\section{ABSTRACT}

Speaking skills are one of the language skills, where speaking skills are very important and closely related in learning to communicate, to express ideas, thoughts, and heart well. The problem discussed in this study is how to speak skills using picture story books in Indonesian class III students. This study aims to describe speaking skills with picture story books in Indonesian subjects for third grade students at SD Negeri Pasar Baru 1 Tangerang City. This research is qualitative research with the subject of 20 students in class III and class III teachers. The techniques used to collect data are tests, third grade teacher interviews, third grade teacher observations, third grade student observations, documentation and data analysis carried out by data reduction, data presentation, and drawing conclusions. The conclusions of this study indicate that speaking skills by picture story books are good, in 7 aspects that are assessed, namely: story content, accuracy of story telling accuracy, story accuracy, story meaning accuracy, word accuracy, sentence accuracy, accuracy, from 20 students there are 8 students who have not mastered aspects of speaking skills through story books.

Keywords: Speaking Skills, Picture Story Books.

\section{PENDAHULUAN}

Secara umum Pendidikan merupakan proses perkembangan kecakapan seseorang dalam bentuk sikap dan perilaku yang berlaku dalam masyarakatnya. Proses sosial dimana seseorang dipengaruhi oleh sesuatu lingkungan yang terpimpin, khususnya di sekolah. Sehingga iya dapat mencapai kecakapan sosial dan mengembangkan kepribadiannya. Selain itu juga pendidikan di tuntut untuk membentuk manusia yang berakhlak mulia, berilmu, cerdas, kreatif, 


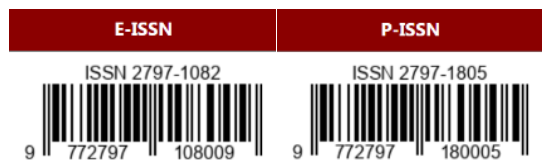

mandiri dan tanggung jawab. Pendidikan sebagai usaha manusia untuk menumbuhkan dan mengembangkan potensi-potensi pembawaan baik jasmani maupun rohani sesuai dengan nilai-nilai yang ada didalam masyarakat dan kebudayaan. Usaha-usaha yang dilakukan untuk menanamkan nilai-nilai dan norma-norma tersebut serta untuk dikembangkan dalam hidup dan kehidupan yang terjadi dalam suatu proses pendidikan.

Berdasarkan Undang-undang No.20 Tahun 2003 pasal 1 ayat 1, pada umumnya pendidikan adalah menyediakan lingkungan yang memungkinkan anak didik untuk mengembangkan potensi dirinya secara optimal, agar dapat mencapai standar kompetensi lulusan satuan pendidikan. Sesuai dengan bunyi Undang-undang RI No. 20 Tahun 2003 pasal 3 ayat 3 tentang SISDIKNAS yang berbunyi pendidikan nasional berfungsi mengembangkan kemampuan dan membentuk watak serta peradaban bangsa yang bermartabat dalam mencerdaskan kehidupan bangsa, yang bertujuan untuk mengembangkan potensi peserta didik agar menjadi manusia yang beriman dan bertaqwa kepada Tuhan Yang Maha Esa, berakhlak mulia, sehat, berilmu, cakap, kreatif, mandiri dan menjadi warga negara yang demokratif serta bertanggung jawab. Seperti yang tercantum dalam Permendikbud No. 20 Tahun 2016 tentang Standar Kompetensi Lulusan Pendidikan Dasar dan Menengah, setiap lulusan satuan pendidikan dasar dan menengah memiliki kompetensi pada tiga dimensi yaitu sikap, pengetahuan, dan keterampilan. Pendidikan berguna untuk membangun kehidupan masa kini dan masa depan yang lebih baik dari masa lalu dengan berbagai kemampuan intelektual, kemampuan berkomunikasi, sikap sosial, kepedulian, dan berpartisipasi untuk membangun kehidupan masyarakat dan bangsa yang lebih baik.

Fenomena pendidikan nasional saat ini dihadapkan pada beberapa permasalahan yang menonjol yaitu masih rendahnya pemerataan memperoleh pendidikan, masih rendahnya kualitas dan relevansi pendidikan, dan masih lemahnya manajemen pendidikan di samping belum terwujudnya kemandirian dan keunggulan ilmu pengetahuan dan teknologi. Dalam rangka peningkatan mutu pendidikan di Indonesia, pendidikan nasional harus mampu menjamin pemerataan kesempatan pendidikan, peningkatan mutu dan relevansi serta efisiensi manajemen pendidikan. Pemerataan kesempatan pendidikan diwujudkan dalam program wajib belajar 9 tahun, peningkatan mutu pendidikan diarahkan untuk meningkatkan kualitas manusia Indonesia seutuhnya melalui olah hati, olah pikiran, olah rasa dan olah raga agar memiliki daya saing dalam menghadapi tantangan global. Peningkatan relevansi pendidikan dimaksudkan untuk menghasilkan lulusan yang sesuai dengan tuntutan kebutuhan berbasis potensi sumber daya alam Indonesia.Peningkatan efisiensi manajemen pendidikan dilakukan melalui penerapan manajemen berbasis sekolah dan pembaharuan pengelolaan pendidikan secara terencana, terarah dan berkesinambungan (Depdiknas, 2006:6).

Bahasa adalah suatu alat komunikasi yang juga berfungsi sebagai media bagi pencapaian beberapa tujuan seperti meningkatkan intelektualitas peserta didik, sarana penyaluran emosional dan sosial serta membantu dalam pencapaian keberhasilan di bidang studi (mata pelajaran) lain. Dengan dikuasainya keterampilan berbahasa, maka peserta didik akan mudah mengemukakan ide dan pemikirannya, serta mengungkapkan emosi dan kreasi serta partisipasi aktif dalam setiap forum yang melibatkan orang banyak. Dalam pembelajaran bahasa, aktivitas melakukan sesuatu tersebut terkait dengan kompetensi berbahasa, baik secara aktifreseptif (menyimak dan membaca), aktifproduktif (berbicara dan menulis). Kompetensi berbahasa mencakup 4 keterampilan, yaitu: menyimak, berbicara, membacadan menulis. Selain itu adapula aspek penunjang yaitu keterampilan berbicara, berbicara merupakan salah satu keterampilan berbahasa yang harus dikuasai oleh peserta didik. Keterampilan berbicara ini 


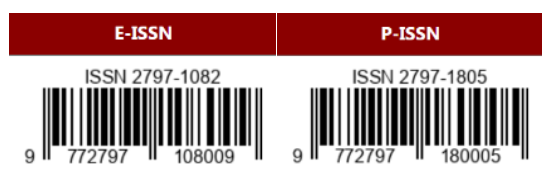

sangat diperlukan agar mereka mampu melakukan komunikasi baik interpersonal maupun intrapersonal. Sebagai contoh ketika kegiatan presentasi, bernyanyi, diskusi bahkan ketika melakukan debat dengan peserta didik/kelompok lain. Keterampilan berbicara yang baik akan sangat berguna ketika peserta didik kelak melanjutkan sekolah ke tingkat yang lebih tinggi, SD sampai tingkat perguruan tinggi pasti akan membutuhkan keterampilan dalam berbicara, oleh karena itu, mata pelajaran bahasa Indonesia dalam dunia pendidikan di Indonesia diarahkan untuk mengembangkan 4 keterampilan tersebut dan aspek penunjang agar lulusan mampu berkomunikasi dan berwacana dalam bahasa Indonesia dalam tingkat literasi tertentu.

Keterampilan berbicara sangat penting dikuasai oleh siswa. Karena berbicara merupakan pelajaran yang menjadi dasar atau landasan tingkat pendidikan yang lebih tinggi. Seandainya dasar tersebut kurang kuat, niscaya pengaruhnya cukup besar yang sangat terasa, baik para siswa sendiri atau juga oleh guru. Berbicara adalah suatu proses interaksi atau berkomunikasi untuk menyampaikan makna dari yang tertulis, melibatkan aktivitas visual, berpikir, psikolingustik, dan metakognitif. Manfaat dari berbicara yaitu dapat membuka kepercayaan diri yang berpadu dengan kerendahan hati.

Ciri kecenderungan belajar anak usia sekolah dasar adalah konkret, integratif, dan hierarkis. Konkret mengandung makna proses belajar beranjak dari hal-hal yang konkret, yakni penggunaan media yang dapat dilihat, didengar, dibaui, diraba, dan diutak-atik dengan titik penekanan pada pemanfaatan lingkungan sebagai sumber belajar. Integratif mengandung makna bahwa pada tahap usia sekolah dasar anak memandang sesuatu yang dipelajari sebagai suatu keutuhan, belum mampu memilah-milah konsep dari berbagai disiplin ilmu. Adapun hierarkis mengandung makna bahwa cara anak belajar berkembang secara bertahap, mulai dari hal-hal yang sederhana ke hal-hal yang lebih kompleks.
Berdasarkan hasil observasi awal yang dilakukan peneliti dengan guru pada hari Kamis, Tanggal 18 Februari 2021 di kelas III Sekolah Dasar Negeri Pasar Baru 1 Kota Tangerang. Dengan jumlah 20 siswa di kelas III, masih terdapat beberapa siswa yang belum mendaptkan hasil maksimal (nilai dibawah KKM yaitu 70), dan beberapa hal yang mempengaruhi diantaranya: pengucapan kata atau kalimat yang kurang, contohnya seperti sering mengulang-ulang kata dalam bercerita, ketepatan penggunaan bahasa masih kurang contohnya seperti kata di sana menjadi di sono, malu-malu untuk berbicara di depan kelas atau kurang percaya diri ketika materi pembelajaran bercerita sehingga terlihat kurang serius dalam keterampilan berbicara dan kurang aktif dalam proses pembelajaran.

Berdasarkan uraian di atas, maka peneliti tertarik untuk mengetahui keterampilan berbicara siswa kelas III Sekolah Dasar Negeri Pasar Baru 1 Kota Tangerang melalui penelitian yangberjudul Analisis Keterampilan Berbicara Melalui Penggunaan Buku Cerita Bergambar Pada Mata Pelajaran Bahasa Indonesia Siswa Kelas III SD Negeri Pasar Baru 1 Kota Tangerang.

\section{METODE PENELITIAN}

Penelitian ini menggunakan pendekatan kualitatif, dengan jenis metode penelitian kualitatif deskriptif. Penelitian ini dilakukan dengan berdasarkan temuan di lapangan tentang memberikan suatu gambaran apa adanya dan tanpa ada rekayasa yang terjadi di dalam penelitian. Agar peneliti dapat mendeskripsikan secara jelas dan rinci serta mendapatkan data yang mendalami mengenai "Analisis Keterampilan Berbicara Melalui Penggunaan Buku Cerita Bergambar Pada Mata Pelajaran Bahasa Indonesia Siswa Kelas III SD Negeri Pasar Baru 1 Kota Tangerang". Hal yang sangat diutamakan dalam penelitian kualitatif yaitu dapat mengungkapkan suatu data dan informasi yang dapat ditarik makna dan konsepnya.

Dalam penelitian model analisis kualitatif yang digunakan adalah model Miles dan 


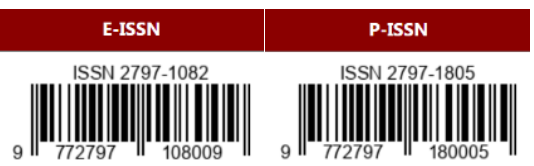

Huberman yang meliput : reduksi data (memilih data yang penting, relevan, dan bermakna dari data yang tidak berguna), sajian deskriptif, (narasi, visual gambar, tabel) yang sistematis dan logis dan penarikan kesimpulan. Instrument penelitiannya dapat berupa tes, pedoman wawancara, pedoman observasi dan pedoman dokumentasi, dan kuesioner. Dalam penelitian ini instrument yang digunakan peneliti yaitu menggunakan tes, wawancara dan dokumentasi. Peneliti menggunakan instrument ini dengan melakukan uji expert judgement dengan Dosen kebahasaan Universitas Muhammadiyah Tangerang.

Dalam penelitian ini, peneliti akan menggunakan teknik analisis data yang telah dipaparkan. Tujuan dari penelitian ini yaitu untuk mengetahui keterampilan berbicara melalui penggunaan buku cerita bergambar pada mata pelajaran Bahasa Indonesia siswa kelas III SD Negeri Pasar Baru 1 Kota Tangerang. Dengan menggunakan teknik pengumpulan data dan menghasilkan data yang sebenarnya.

\section{HASIL DAN PEMBAHASAN}

Pembahasan hasil penelitian ini dimaksud untuk mengetahui keterampilan berbicara melalui penggunaan buku cerita bergambar pada mata pelajaran bahasa Indonesia siswa kelas III SD Negeri Pasar Baru 1 Kota Tangerang. Berdasarkan hasil penelitian pada kelas III, jumlah sampel sebanyak 20 siswa. Yang akan dinilai berdasarkan 7 aspek yaitu kesesuaian isi cerita, ketepatan penunjukkan detil cerita, ketepatan logika cerita, ketepatan makna keseluruhan cerita, ketepatan kata, ketepatan kalimat, kelancaran.

Setelah penelitian keterampilan berbicara melalui penggunaan buku cerita bergambar dilakukan, maka dapat disimpulkan bahwa keterampilan berbicara melalui penggunaan buku cerita bergambar pada siswa kelas III terdapat 8 siswa belum cukup baik dalam keterampilan berbicara yang dinilai pada 7 aspek.

\section{KESIMPULAN DAN SARAN}

Berdasarkan analisis data dan pembahasan dapat disimpulkan bahwa keterampilan berbicara siswa kelas III dalam bercerita sudah cukup baik. Pada 7 aspek yang dinilai yaitu: kesesuaian isi cerita, ketepatan penunjukkan detil cerita, ketepatan logika cerita, ketepatan makna keseluruhan cerita, ketepatan kata, ketepatan kalimat, kelancaran, dari 20 siswa terdapat 8 siswa yang belum memenuhi aspek keterampilan berbicara melalui buku cerita.

Berdasarkan kesimpulan yang telah diuraikan. Maka peneliti mempunyai beberapa saran untuk beberapa pihak yaitu:

a. Bagi Guru

Keterampilan berbicara siswa kelas III SD Negeri Pasar Baru 1 Kota Tangerang masih perlu ditingkatkan. Peneliti menyarankan bagi guru untuk memperbanyak interaksi dengan siswa ketika proses pembelajaran berlangsung untuk merangsang keingintahuan siswa serta melatih keterampilan berbicara siswa serta guru juga harus senantiasa memberikan motivasi kepada siswa agar siswa lebih bersemangat dalam bertanya dan memberikan pendapatnya ketika proses pembelajaran berlangsung.

b. Bagi Sekolah

Peneliti harap kepada pihak sekolah seharusnya ikut bekerjasama dengan guru dan memberikan solusi untuk membantu keterampilan berbicara siswa.

c. Bagi Peneliti

Bagi peneliti selanjutnya untuk tidak meremehkan tentang keterampilan berbicara siswa. Karena keterampilan berbicara merupakan keterampilan berbahasa yang sangat penting. Diharapkan peneliti selanjutnya untuk melanjutkan penelitian tentang keterampilan berbicara siswa agar keterampilan berbicara siswa bisa terus meningkat. 
d. Bagi Institusi

Bagi institusi diharapkan ini dapat dijadikan bahan referensi tentang keterampilan berbicara siswa, dan menambah wawasan peneliti sebagai bekal untuk masa mendatang.

\section{DAFTAR PUSTAKA}

Arianti, R. (2019). Petunjuk Praktis Pengajaran Keterampilan Berbicara. Yogyakarta: Deepublish Publisher.

Fadhillah, D., \& Hamsanah, H. S. (2018). Pembelajaran Bahasa Indonesia Kelas Rendah.Yogyakarta: Samudra Biru.

Fadhillah, D., Hamsanah, H. S., \& Latifah, N. (2019). Pembelajaran Bahasa Indonesia Kelas Tinggi.Yogyakarta: Samudra Biru.

Jayadi, U. (2021). Penerapan Metode Pembelajaran Cooperative Integrated Reading And Composition (Circ) Untuk Meningkatkan Hasil Belajar Dalam Menemukan Kalimat Utama Pada Siswa Kelas IV SDN 22 Mataram Tahun Pelajaran 2020/2021. Berajah Journal, 1(1), 21-42. https://doi.org/10.47353/bj.v1i1.17

Magdalena, I., \& Huliatunisa, Y. (2020). Evaluasi Pembelajaran $S D$.Tangerang: FKIP UMT Press.

Kadek Dwi Padmawati dkk. (2019). Analisis Keterampilan Berbicara Siswa Kelas V Pada Mata Pelajaran Bahasa Indonesia.Journal for Lesson and Learning Studies Vol. 2 No. 2.

Krissandi, A. D. (2020). Sastra Anak Indonesia. Yogyakarta: Sanata Dharma University Press.

Kurnia, R. (2019). Bahasa Anak Usia Dini. Yogyakarta: Grup Penerbitan CV Budi Utama.
Kurnianingsih, Y., Sinyanyuri, S., \& Assagaf, L. (2018). Menyayangi Tumbuhan dan Hewan Buku Tematik Terpadu Kurikulum 2013 Tema 2 Buku Siswa SD/MI Kelas III. Jakarta: Kementerian Pendidikan dan Kebudayaan .

Madyawati, L. (2017). Strategi Pengembangan Bahasa Pada Anak. Jakarta: Kencana.

Mawardi. (2019). Desain Penelitian Tindakan Kelas. Yogyakarta: Samudra Biru.

Nurgiyantoro, B. (2018). Sastra Anak Pengantar Pemahaman Dunia Anak. Yogyakarta: Gadjah Mada University Press.

Riinawati, Riinawati. (2021). Education Financial Management during Covid19 Pandemic of Islamic Universities in South Kalimantan. Dinamika Ilmu, 21(2), 383-396.

https://doi.org/10.21093/di.v21i2.360 근

Ririn, R. (2020). Analisis Keterampilan Berbicara Dalam Pembelajaran Bahasa Indonesia Pada Siswa Kelas V Sekolah Dasar. Skripsi: Bandung: Universitas Pendidikan Indonesia.

Saputri, W. R. (2018). Analisis Keterampilan Berbicara Siswa Kelas Tinggi Pada Pembelajaran Bahasa Indonesia di SD Negeri

Selo.http://eprint.ums.ac.id//65423/13 INASKAH PUBLIKASI-Rin.pdf.

Sugiyono. (2019). Metode Penelitian Pendidikan (Kuantitatif, Kualitatif, Kombinasi, $R \& D$ dan Penelitian Pendidikan). Bandung: Alfabeta.

Sunardi, D. . (2021). Upaya Meningkatkan Hasil Belajar Siswa Dengan Metode Stem Pada Pembelajaran Reaksi Redoks Di Kelas XII.MIPA1 SMAN 1 Cigugur. Berajah Journal, 1(3), 137-140. https://doi.org/10.47353/bj.v1i3.33 
Sujinah. (2017). Menjadi Pembicara Terampil. Yogyakarta: CV Budi Utama.

Tantawi, I. (2019). Terampil Berbahasa Indonesia (Untuk Perguruan Tinggi). Jakarta : Kencana.

Tarigan, H. G. (2015). Berbicara Sebagai Suatu Keterampilan Berbahasa. Bandung: CV Angkasa. 